\title{
Variations on a Shchi Theme: Collective Dining and Politics in the Early USSR
}

\begin{abstract}
Canteens were a distinctive feature of the USSR during the years of the initial Five-Year Plans. They were intended to be at the core of the formation of the new Soviet citizen. The food they served was therefore supposed to validate the success of the Revolution: white bread, meat, and other good and healthy food were to be concrete markers of the plans' achievements. Huge "factory kitchens" appeared in the main cities of the country. Far from symbolizing the successes of the socialist vision, however, they illustrated to Stalinist Soviet society the fundamental discrepancy between official discourse and reality. Food was scarce; the people suffered from shortages and,
\end{abstract}

Let the worker eat his fill, then the iron industry will fulfill [the plan]. You must feed people better. You will never fulfill the plan with a hungry belly. You need to give more bread and more fat. Then the worker will bear the burden of working. For now, he does not work at the factory, he is just irritable. ${ }^{1}$

These words were penned by an anonymous worker on a note sent to a local party boss who had come to give a speech at the Red Sormovo plant in Gorky on October 27, 1932. By the end of 1932, most Soviet citizens were hungry, in cities and throughout the countryside. Major food shortages were one of the main features of everyday life. Although much is known about the Great Famine that struck Soviet Ukraine, Southern Russia, Kazakhstan, and Western Siberia between 1932 and 1933, which was responsible for up to 8 million deaths (Davies and Wheatcroft 2004), we should not forget that during this period the country as a whole was affected by food scarcity. From 1927 on, after the new Stalinist authorities mandated the end of the New Economic Policy, there were disruptions in both the food supply chain and in retail. ${ }^{2}$ Private trade vanished; state and cooperative shop shelves remained empty, yet most people were unable to shop at farmers' markets, which were prohibitively expensive (Hessler 2004). Food production fell sharply due to the chaos in worst cases, from famine. The canteen nonetheless became one of the few places where Soviet workers and urban dwellers had a relatively reliable access to food, and it also served as a central place of contact between the population and the authorities. The intimate experience of eating became a highly political one, contributing to the formation of homo sovieticus.

Keywords: canteens, Soviet Union, Stalinism, food allocation, food distribution, power

caused by the collectivization of the countryside. Poor harvests, along with the widespread slaughter of livestock by peasants to avoid being collectivized, provoked a dramatic decrease in the amount of food delivered to Soviet cities. A ticket-based rationing system was then implemented from January 1931 until the end of 1934 (Davies and Khlevnyuk 1999: 557-609).

Food was desperately needed in Soviet cities, where huge numbers of new workers had converged. They were attracted by the prospect of working on the large-scale construction works (such as giant factories and dams) initiated as part of the first Five-Year Plan, which aimed to achieve the rapid industrialization of the country. This burgeoning urban population therefore had to be fed in the context of famine or quasi-famine. State and party authorities played a major role in allocating the scarce food resources, as market mechanisms were almost totally banished. They had different tools at their disposal, but canteens were a crucial part of this policy.

The role of the state in food politics is not specific to the USSR: there is no shortage of examples throughout history, and outside the borders of Russia, that demonstrate the importance of this issue. ${ }^{3}$ One of the most famous elements of the Gracchi reforms in Republican Rome was the so-called frumentary laws, often interpreted as part of a broader struggle between rival factions to gain the support of the people. Here wheat was to 
be distributed at artificially low prices to an ever-growing number of inhabitants (Virlouvet 1994). Similar policies of manipulating food distribution can be seen in such institutions as the praefectus annoane ("Prefect of the Provisions") in imperial Rome, the "police du pain" in modern France (Kaplan 1976; Dando 2012: 274-75), and in the management of food and grains in Rome during the seventeenth and eighteenth centuries. George E. Munro (1997) has convincingly shown how food was an instrument of power in Saint Petersburg, as in Rome: both cities were consuming far more food than they were producing.

In the context of food scarcity or hunger, food allocation is even more political, as emphasized by various scholars. For instance, Inna Zweiniger-Bargielowska (2011) demonstrates how food scarcity led to a consumption hierarchy in wartime Britain. Enrique Ochoa shows how the state food agency founded by Mexican president Lázaro Cárdenas in 1937 made the state a major actor in the food politics of the countryside and the cities, where high prices and rapid urban growth produced crisis conditions. The agency organized a state-supported food distribution network and promoted consumer cooperatives (Ochoa 2000: 48-61). While this dirigisme of the Mexican state shares some features with the Soviet case, Bolshevik authorities went a step further, not limiting themselves to the distribution of raw food and materials. They chose also to develop a vast network of canteens throughout the country. These were organized in most factories, in the workers' districts of the industrial towns, in the city centers, and even in the countryside. Their size varied considerably, but they were tasked with feeding an average of 30-100 people.

The Bolshevik policy clearly mimicked a broader European trend: collective dining halls had been built since the end of the nineteenth century, particularly during World War I (Gacon 2014). A similar trend can be seen in 1930 Britain (Long 2014) and in Fascist Italy (Ricciardi 2014), but nowhere did canteens acquire the same level of practical and ideological importance as in the USSR. To be sure, a similar mushrooming of canteens took place later in Communist China during the

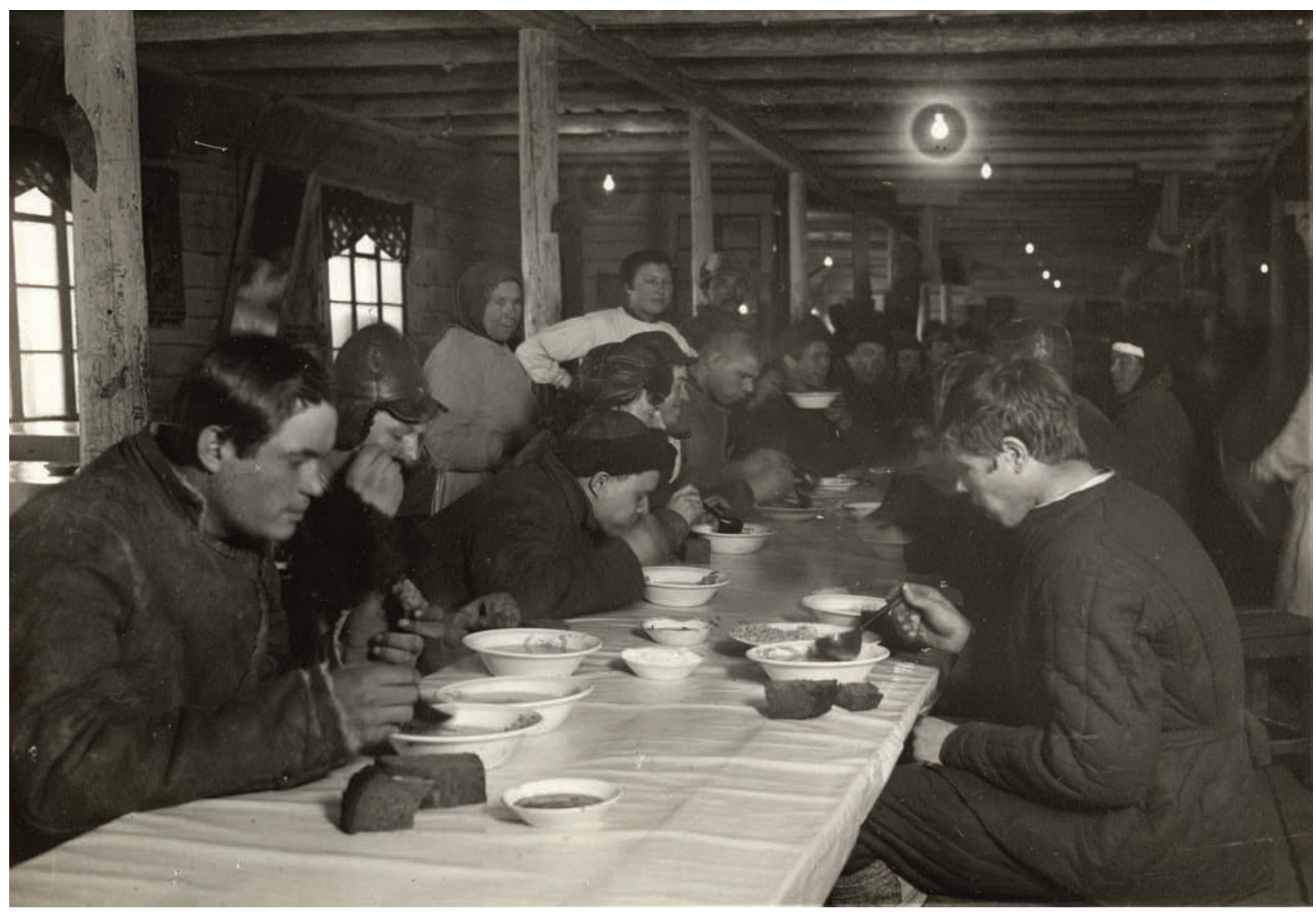

FIGURE 1: First canteen of the building site of Ural Machine Factory (Uralmach), 1928-29. 
Great Leap Forward (1958). The effects were the reverse, however, since in China state canteens were a major contributor to famine, whereas in the USSR they were part of the answer to it (Yang 2012: 174-96).

Factory canteens were also part of the broader ideological project of communal living, promoted by the new Bolshevik authorities as soon as they took power in October 1917. In addition to feeding the population, canteens aimed to create the New Man. They too were conceived as a tool designed to free women from "kitchen slavery." More importantly, it is here that the "bourgeois way" of feeding oneself would disappear once and for all (Nérard 2014: 87-92). While the canteen trend experienced unprecedented growth between 1918 and 1924, that early attempt failed (Borrero 2003: 143-56; Borrero 1997) and most were subsequently closed. The dream was never abandoned, however. During the 1920s the first "industrial kitchens" (fabriki kukhni) were built. Symbols of the new socialist world (Olesha and Schwartz 2004), ${ }^{4}$ these establishments were designed to generate huge numbers of meals using extensive mechanization. ${ }^{5}$

With the worsening of the food situation at the beginning of the 1930s the Soviet leadership decided, once again, to rely on collective catering. Canteens were opened across the country, so that by 193214.8 million meals were being served every day in factory canteens (Hessler 2004: 177). Grandiose in its inception, the effective implementation of the canteens, however, was complicated by dire shortages at the beginning of the 1930s. In addition, politicians and industrial managers seemed more interested in fulfilling plan quotas than in actually feeding the workers.

Food allocation and dining were one of many areas where the discrepancies between official rhetoric and reality stood out. A great deal has been said about the disjuncture between the real and the ideal in the context of 1930 Stalinism (Goscilo 2009: 55). Although the symbolic aspects of the canteen movement have been thoroughly documented (for example, Rothstein and Rothstein 1997), little attention has been paid to the actual functioning of Soviet canteens during the major period of the initial Five-Year Plans. ${ }^{6}$ This article will therefore focus on the ways in which collective catering was organized and its subsequent functionality. Drawing on a number of archival sources, I provide a case study dealing with a major Soviet industrial town, Nizhny Novgorod. ${ }^{7}$ It was in this city where the Gorky automobile plant, one of the main projects of the First Five-Year Plan, was implemented, but the city also served as a center for other major industrial plants (most notably, shipyards).

I will argue that this study, at a very local level, of Soviet power in practice furthers our understanding of the Soviet system. As proposed by Melissa L. Caldwell (2009: 3), I took "food seriously as a starting point for exploring the political, economic, social, and cultural transformations." Since BrillatSavarin's Physiologie du gout (1825), scholars have stressed the role played by food in the forming of identity (Bruegel and Laurioux 2002, among many others). Thinking of "the wooden spoon," more than often used in Stalinist canteens, "and not

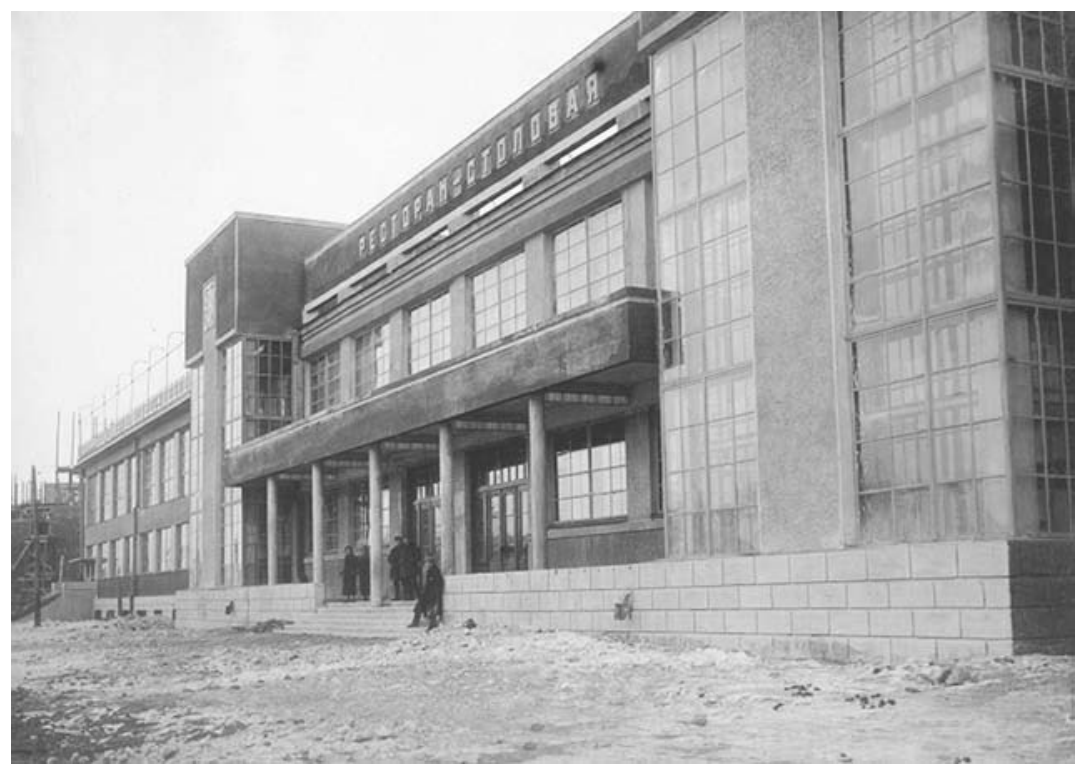

FIGURE 2: Building of the industrial kitchen (fabrika kuhnia), 1932.

COURTESY OF URALMASHZAVOD MUSEUM IN YEKATERINBURG 
only the scepter" (Goldstein 2001: 2), helps us to understand the nature of Stalinist society. Caldwell (2009: 3) underlines that food consumption is the moment when the political is made personal. Canteens were a place where the Soviet individual was crafted. The intimate experience of eating badly had political consequences, and was a vital component in structuring the eaters' relationship to Soviet power. The political dimension of eating is at the core of this article.

\section{Soviet Menus}

Soviet authorities' approach to food production and catering can come across as primarily quantitative, leaving little room for consideration of the quality or appeal of the food itself. Archival sources are full of figures on turnover and sales, estimates of the number of workers attached to each canteen, as well as the precise number of dishes produced. These figures, as impressive as they may initially appear, are often meaningless. In order to obtain them, Soviet administrators in essence combined "apples and oranges," lumping together dishes with varying caloric and nutritional values, such as simple glasses of kisel, bowls of soup, mashed potatoes, and meat goulash. ${ }^{8}$ For example, canteens at the Gorky automobile plant produced 147,000 "dishes" a day in $1932 .{ }^{9}$

Still, it would be a mistake to assume that what was actually served to the workers did not matter to either the authorities or the consumers. The Bolsheviks themselves were without a doubt cognizant of the political dimension of food. Pierre Bourdieu, in his well-known study of the sociology of taste (Bourdieu 1984), emphasized the link between alimentation practices and social distinction: he drew a "food space" chart where aliments were divided according to social repartition (186). To Bourdieu, observing 1970s France, "the working-class meal is characterized by plenty," and privileged aliments are bread and pork, as opposed to fruit and fish. The social hierarchy of foods (Grignon and Grignon 1980) played a significant role in Soviet society, as well. And Bolsheviks leaders were certainly aware of it.

For instance, during a July 1928 meeting of the Central Committee, one of the main decision-making organs of the Communist Party, Bolshevik leaders debated the symbolic value of white versus black bread. In order to deal with the first signs of shortages, it was proposed that white bread should be taxed and black bread subsidized. Yet most of the leaders opposed the idea. One of the benefits of the Revolution had to be, according to some of them, the possibility of eating white bread. Mikoyan, then People's Commissar for Trade, explicitly claimed: "Before, we ate black bread, and now we are eating white bread. We made the Revolution in order to eat more than just black bread." Indeed, he went even further in his political analysis of food (Danilov et al. 2000: 427, 445):

Now if there is not enough butter they [the workers] immediately start grumbling. If we say to the worker: "wait, eat something else, leave the NEPmen [the new rich people, entrepreneurs who benefited from the opportunities for private trade created by the New Economic Policy] to eat white bread and butter," the worker would correctly answer: "why have we made the Revolution if I cannot fill myself with butter, eggs and white bread?" Even the fact that we began to sell gray bread provoked dissatisfaction among the workers.

This idea that the Revolution had to have alimentary consequences, not only in quantitative terms (i.e., the ability to fill one's stomach), but also in terms of the quality of food, is very much present in Soviet official discourse. If such an idea was temporarily abandoned during the worst years of famine, it came back as early as 1936 (Glushchenko 2010: 66-70), when the development of champagne production was based on the notion that "champagne is a sign of material well-being, a sign of prosperity" (Gronow 2003: 17). As Mikoyan goes on to say: "Comrade Stalin remarked that Stakhanovites [the elite of the workers, who set production records and were accordingly rewarded by many material privileges] nowadays earn a lot of money, as do engineers and large numbers of other workers. But, if they want to buy some champagne, will they be able to do that?" (Ministry of the Food Industry 1954).

That actual food distribution fell short of promises. Menus for the year 1932 from canteen no. 27 of a chemical plant in Nizhnii Novgorod give us a good overview of what was served. The 120 workers who ate there were offered a two-course lunch consisting of soup and a main course. During the twenty-five working days of February, workers were given cabbage soup (shchi) under different names on five occasions. There was also borscht, a soup made of cabbage and beets (offered four times during the month). Other soups were made from peas, potatoes, or pasta. Meanwhile, the main course contained meat and fish only six times. The rest of the month - half of it, to be precise-workers were to eat pasta or cereals (buckwheat groats [four times] or millet porridge [five times]). ${ }^{10}$ As monotonous as they might appear, the menus for February 1932 were nevertheless quite exceptional and were even nominated as part of a competition for the best canteen in the region! These menus demonstrate, however, structural characteristics that were actually quite common across the period studied-that is, the omnipresence of soups, the recurrence of the same dishes (or even the same ingredients) with relatively high frequency, as well as the near absence of fresh fruits and green vegetables.

Huge disparities were the rule as canteens and the food they served were not isolated from the larger hierarchy of 


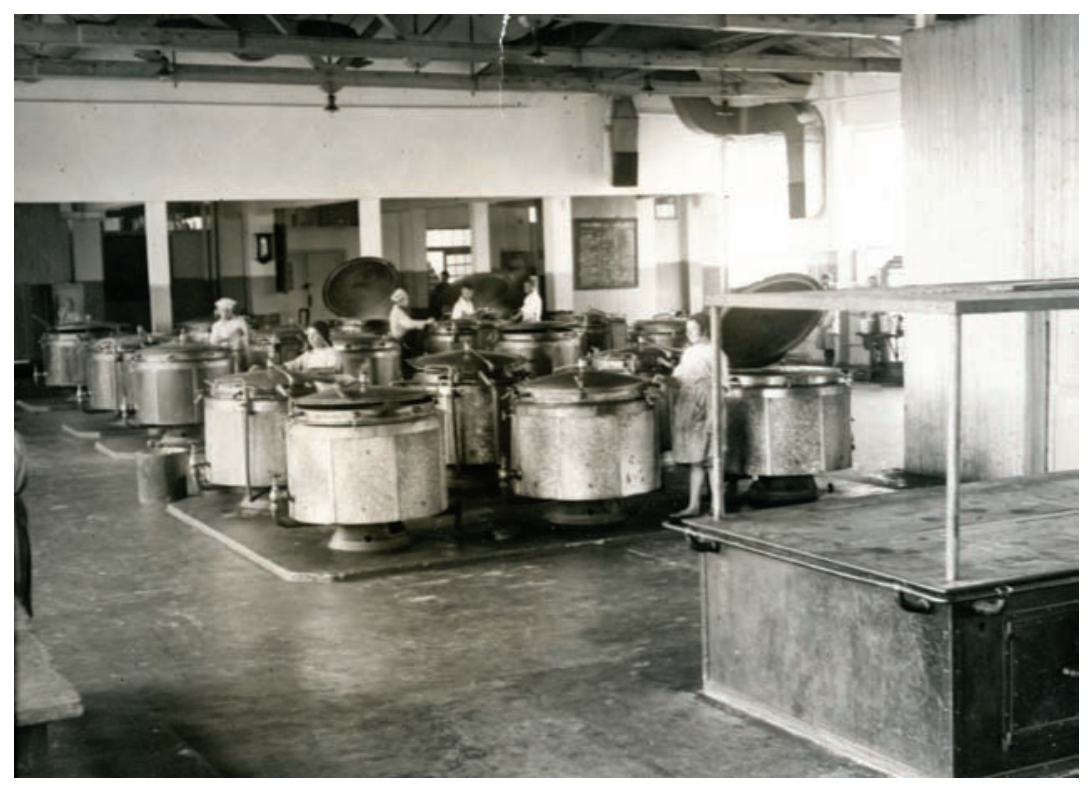

FIGURE 3: Soup cookware in the industrial kitchen (fabrika kuhnia), 1932.

COURTESY OF URALMASHZAVOD MUSEUM IN YEKATERINBURG

consumption, so well described by Elena Osokina (2001: 65) as a kind of "industrial pragmatism." The rationing system excluded the vast majority of Soviet people (i.e., rural inhabitants), while providing different levels of access to food depending on the enterprise where people worked. Forty percent of the workers received from 70-80 percent of the centralized food resources (Osokina 1998: 90). In addition, there were also significant differences from one factory to the next. Workers were divided into separate categories depending on their importance to the factory or the difficulty of their task. In April of 1934, workers from the first two categories at the Krasnoe Sormovo Shipyard received meat every day, while those in the third group could eat meat only eighteen days a month, and that limit was lowered to ten days for those in the fourth group. ${ }^{11}$ Food was also one of the main work incentives: shock workers (udarniki)-that is, those who exceeded their obligations and were regarded as the hardest-workingwere to be rewarded by being better fed, either quantitatively or qualitatively. ${ }^{12}$ They benefitted from separate dining rooms, tablecloths, and more appealing menus: notably, meat was more abundant (but other scarcer items might also have been served, such as sour cream in the soup). ${ }^{13}$

This is a general model of the food served in Stalinist canteens, but one cannot rely exclusively on the menus preserved in the archives to provide an accurate picture of what was actually on the plates of Soviet workers. Despite slight differences in nomenclature, the reality was most often of grim monotony and poor quality. Preparation left much to be desired. Cases of badly cleaned fish or poorly peeled potatoes were not uncommon. The contents of the workers' meals were sometimes truly surprising, including objects and ingredients that one would not expect to find in them. In 1932, at canteen no. 6 of the Krasnoe Sormovo factory, workers discovered cigarette butts and some pieces of tin in their soup. Cockroaches floated in the shchi, ${ }^{14}$ and pieces of broken glass were also disturbingly common. ${ }^{15}$

The presence of these "foreign" objects (postoronnie predmety), as they were called in the reports of Soviet inspectors, never ceased to puzzle managers and consumers. Political interpretations were generally preferred over more technical or logical ones. When a rat was found in the soup of workers in Krasnoe Sormovo in October 1931 the local Union found it necessary to conduct a special inquiry in order to unmask a possible saboteur. When the conclusion happened to be rather unremarkable ("the rat had jumped into the pot on its own"16), the regional party committee found time to discuss it, as if it was not obvious. In May 1934, the inspectors conducted an inquiry into the discovery of mice droppings in the soup served at the Red Etna factory, and produced a report numbering several pages with the conclusion that "there is reason to believe that this was a malicious act of class enemies." ${ }^{\prime 7}$ This notion of sabotage linked to the presence of foreign objects in food continued throughout the 1930 s and was widely exploited during the great wave of repression from 1937 to $193^{8}$.

Neither the quantity nor the quality was sufficient in the canteens during the initial Five-Year Plans. Workers were 


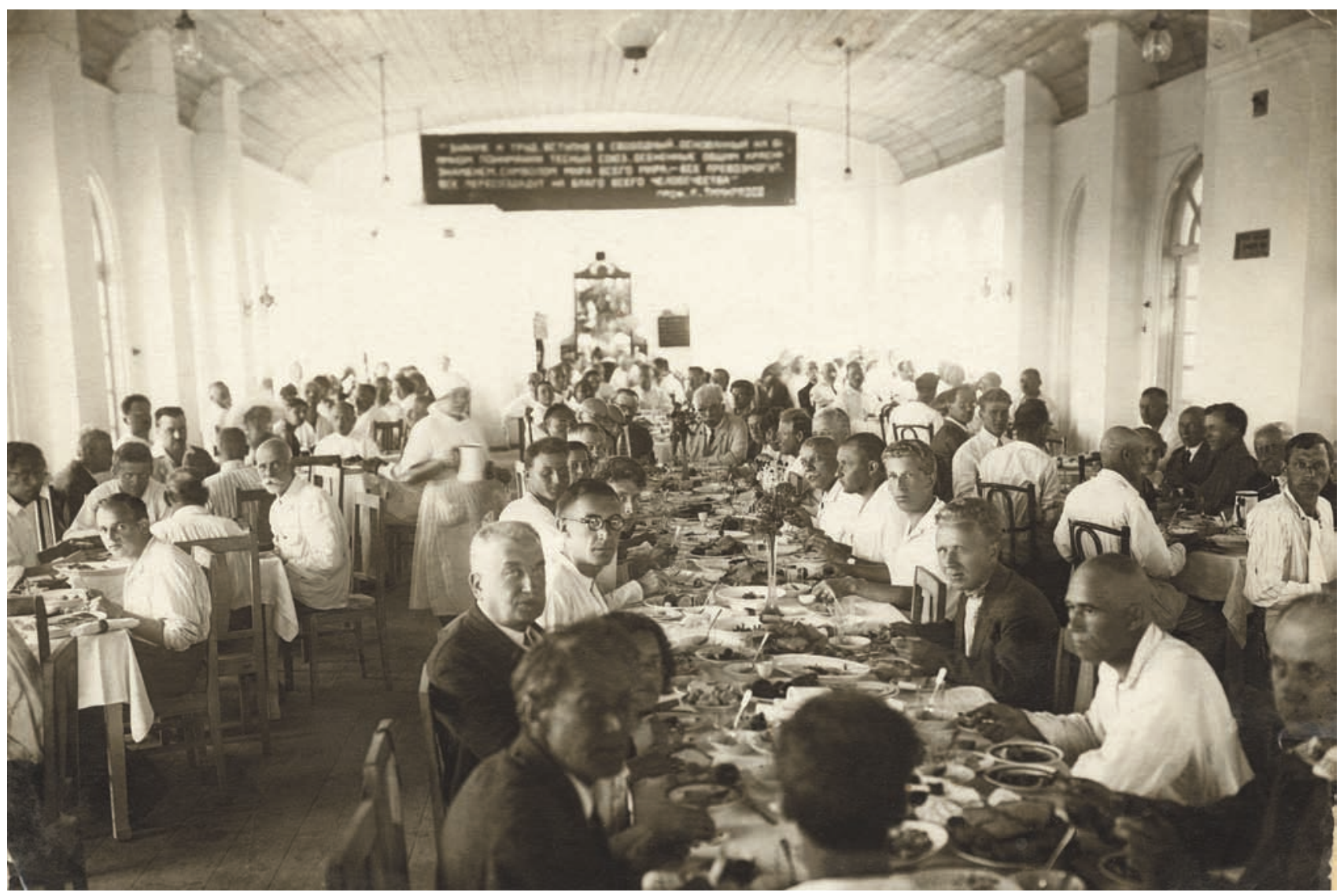

FIGURE 4: Gala dining for the opening of the factory, July 15, 1933.

COURTESY OF URALMASHZAVOD MUSEUM IN YEKATERINBURG

steadily presented with a discourse of modernity where "the future of socialism was always conceived in terms of plenty" (Fitzpatrick 2003: 19), yet they had to eat monotonous, unhealthy, and often disgusting food. This discrepancy was bound to have political consequences. The Stalinist leaders were, however, fully aware of the political role played by the food served in the only spots where it was available in a hungry USSR. At least before 1935, central and regional authorities worked persistently toward merging discourse with reality in terms of food, but the results of their efforts proved unconvincing.

\section{The Impossible Quality of Food}

In order to understand the erratic functioning of Soviet canteens, one needs to look at where the food was produced and especially at the supply chains that delivered it. The supply network was a primary source of the chaos that reigned in the Soviet collective catering system. Four major sources of supply were available to the canteen managers: the state-controlled warehouses, factory farms, collective farms, and private trade.
With the end of the New Economic Policy, the main supply source became the centralized state system. The food it managed was then distributed to the workers inside the factories through different structures known as "closed distributors" and, after 1932, "departments of worker provisionment" (Hessler 2004: 178-80). These various sources of supply were subject to great pressures. The very limited amount of food resources forced the authorities to allocate them according to their priorities. As a result of the chaotic management of resources, food storehouses were often empty and sometimes cooks found themselves with nothing to cook.

To address this problem, cooks and canteen directors were asked to broaden their supply chains. They were encouraged to set up so-called factory farms, directly dependent on the factory and located more or less next to the plant. The results of this policy were mixed. Some factories managed to collect small amounts of food in this way, but for most the results were unsatisfactory. In May 1934, the Red Etna metalworking factory had a farm with 21 cows, 116 pigs, and 475 acres of land to feed the 3,498 workers eating in the factory's 
canteens. But even after almost two years, the farm production consisted mainly of "vegetables." 18 Seventy percent of the livestock of the automobile plant farm suffered from infection and therefore produced very small quantities of milk (an average production of 1.5 to 2 liters a day per cow). ${ }^{19}$

Another way of coping with the dysfunctional state-centralized system was via so-called self-supply. This consisted of sending certain officials to the surrounding countryside to buy food products or to barter for them - in exchange for industrial production. Some reports even call this practice "Soviet-style trade." In this manner the "Engine of the Revolution" factory was able to acquire more than forty tons of meat $(88,000$ pounds) that were distributed to the workers in the factory shop and in the canteens. ${ }^{20}$ But these successes were decidedly not the rule: in the newly collectivized countryside, officials from the cities were mostly greeted warily or with open hostility.

Finally, collective farm markets became a major source of supply after their legalization in May 1932 (Hessler 2004: 189-91). Here again, collective catering serves as a concrete marker of the failures of the Stalinist vision, because paradoxically it was the private sector that allowed the state system to survive rather than collapse. The only way for cooks and canteen directors to feed the workers and avoid major work disruptions was to buy at such "private markets" the food they were unable to obtain through official channels. At the same time, the use of private markets had the unintended effect of weakening the state system, further exacerbating the deficits associated with Soviet canteens. The price of food at such markets - noticeably higher than at state ones - did not fit within the budget of the canteens that were established on the basis of state prices. Thus, each supply source exacerbated tensions, diminished work efficiency, and led to financial imbalances.

The second major bottleneck in the system was linked to transportation. This was a significant problem in general in the USSR, but had especially severe consequences for collective catering because the whole system was based on the geographical separation between where the food was processed and where it was consumed. The construction of big industrial kitchens was a high priority. Due to their huge capacity, the food they produced was dispatched among the different canteens using thermos technology. This system had important consequences for food quality, as remarked by R. S. Zemliatchka, an inspector coming from Moscow, one of the heads of the Workers' and Peasants' Inspectorate (RKI):

Food is taken away, from this kitchen where it goes rotten, in thermos [containers] to the shop floor canteens. I have seen the way they were carried. They drive the trolley on a very badly maintained path, with huge holes in the middle. Even before it reaches the workers, the food is all mixed up. ... [The] thermos [containers] were filled up with soup mixed with meat and porridge. ${ }^{21}$

The system proved so inadequate that during the particularly difficult years of 1931-32 Soviet authorities abandoned it, whereas only months before it had been presented as the height of modernity and therefore fully financed.

An additional problem had to do with the quality of the ingredients, regardless of their quantity. This is partly explained by the conditions of production, particularly for meat. In October 1932, meat (mostly beef) production in the Gorky province was only 25.6 percent of what had been expected. Animals handed over to slaughterhouses were weak, losing weight, malnourished, and therefore of poor quality. ${ }^{22}$ Moreover, canteens were always considered a low priority, a place where consumers had no choice but to eat what they were given. Fruit too wormeaten to be sold in shops was sent to canteens. ${ }^{23}$

Even if they were not damaged, foodstuffs often reached the kitchens in a poor state due to unsystematic and unreliable preservation methods. Alexey Burov, a secretary of the Gorky regional party organization, recalled a visit where he had witnessed the sale of herring that smelled so strong "I couldn't even put my nose near it" and in which "worms were crawling." 24 The specific context of shortages during the years of the initial Five-Year Plans forced many cooks to accept these ingredients for want of anything better. To refuse them was to risk not being able to feed the workers and thus the source of potentially still greater problems. The vast majority of cooks therefore used ingredients that were often barely acceptable. At a meeting with cooks in July 1933, the party head of collective catering was forced to threaten his staff with harsh punishment in cases where they accepted damaged goods:

Remember that, in a case where you accept damaged products, you bear a heavy criminal responsibility. You must carry out a sanitary inspection of the products, an inspection has to be organized at any cost: if not, it will be on your head. You will be brought to justice, you will be locked in a strict isolation cell, you will be judged by a proletarian court. ${ }^{25}$

The problem seemed insurmountable, since the cooks were left with so few alternatives. Refrigeration was also an issue, one that was obviously more acute during summer. Cases of mass food poisoning in factories were not infrequent, such as in 1932, when a soup of rotten bream in Gorky sent several people to the hospital in serious condition, one of whom died. This is not surprising if we take into account the way meat was prepared at the car factory's canteen. Left in a warehouse where the temperature varied from $12-15^{\circ} \mathrm{C}$ for several hours, it was kept, after being boiled, in the kitchen where the temperature was $30-36^{\circ} \mathrm{C}$ for the entire day! ${ }^{26}$ Technical issues 


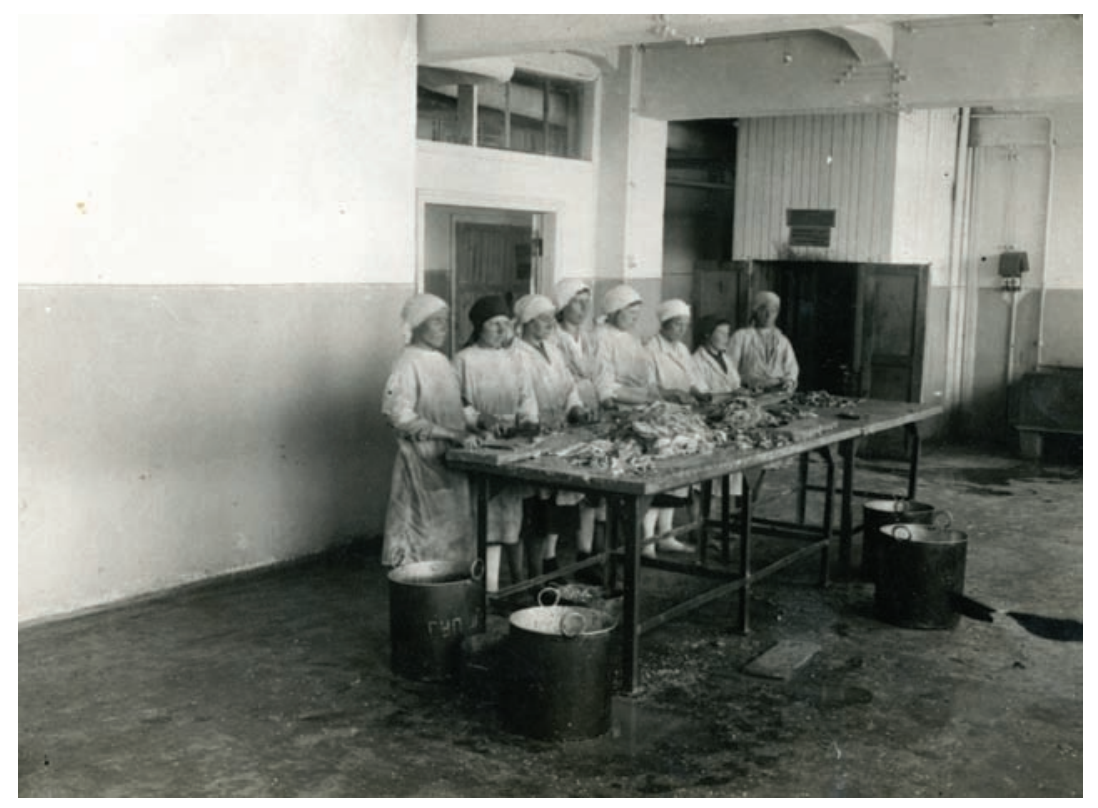

FIGURE 5: Preparation of poultry and meat for lunch at the industrial kitchen (fabrika kuhnia), 1932.

COURTESY OF URALMASHZAVOD MUSEUM IN YEKATERINBURG

and human error combined here to explain the poor quality of food and the risks of poisoning, for the absence of coolers alone cannot explain the lack of care that went into preparing the dishes.

To make matters worse, the staff employed within the collective catering system was largely underqualified. The boom in the number of canteens made it nearly impossible to recruit quality staff. The relatively few professional cooks of the 1920 s (most worked in restaurants) balked at working in collective canteens, as they considered it to be degrading. Moreover, there was not sufficient time to recruit and train new cooks. The Soviet authorities were forced to hire all who applied, even if they had no experience in collective catering. The poor quality of food can thus also be explained by the fact that the cooks simply did not know how to cook. The staff was, moreover, under constant pressure, caught between the discontent of the workers and the requirements of the authorities. The logical consequence of these difficult conditions was a high turnover rate, which did not simplify matters (Nérard 2013).

The poor quality of food in Soviet canteens was almost inevitable, where internal causes combined with external ones to produce a self-reinforcing loop. Authorities were more or less helpless, as demonstrated by the increasing numbers of reports denouncing the system's malfunctions. What were the consequences of this poor food quality for Soviet consumers? What were their reactions to eating such poor food? What were they willing to bear? Do they really, as asserted by one of the Gorky party bosses, "gobble up everything that we give them to eat"? ${ }^{27}$ What were the actual and political consequences of this food system?

\section{Resignation, Frustration, and More}

During the years of food scarcity, most people understood that they had no choice but to eat what they were given, which helps to explain the almost total absence of open demonstrations of discontent. The few revolts and demonstrations of exasperation that can be verified were linked to cases where food was simply so bad it could not be eaten. For example, in February 1933 at canteen no. 23, a textile factory producing coats and professional clothing in the Sverdlov district of Gorky, 250 female workers refused to eat "the shchi and the main course, which were not cooked enough and were exceptionally bitter." ${ }^{28}$ Elsewhere, such as at the locomotive plant of Kharkov in Ukraine, workers twice rejected the "disgusting potatoes" served to them (Aunoble 2001: 13-14).

If hunger prevented more explicit manifestations of discontent, there was nevertheless a great deal of exasperation expressed in the letters received by the head of state, Mikhail Kalinin, in October 1932. Twenty-five percent of all the letters he received (from very diverse geographical regions) focused on the problem of food and hunger. "Had the workers known that they were going to live that life, they would never have 
made the revolution" complained an author disgusted by the "rotten fish" he was given to eat along with "iodized water and cabbage." 29 Indeed, this same worker encouraged the "all-Union Starosta" to come in person and see what the workers were being forced to eat. ${ }^{30}$ Authorities were well aware of the rising tensions surrounding the problem of food. For this reason some Party secretaries refused to discuss the food issue with workers during political meetings at the factories. ${ }^{31}$

After the end of the Hunger of 1932-33, renewed workers' complaints demonstrated that taste preferences were not forgotten. Some reported their disgust at the systematic over-serving of pasta. Others complained about the absence of potatoes, or the fact they were overcooked or poorly cooked. ${ }^{32}$ In any case, workers most frequently expressed their dissatisfaction by "eating with their feet," that is, by leaving their factory to join a new one where they would be better fed. Some even refused to eat at canteens altogether. In April 1934, only 4,925 workers out of a total of 7,303 officially enrolled at the canteens of the chemical plant of Dzherzinsk lunched there. The inspection team commissioned by the provincial authorities was categorical in its conclusions. The significant drop in attendance was due to rising prices, and especially the "lower quality food linked to decreased production of meat dishes." 33 The lowest priority workers of that plant received only twelve meat dishes during the second quarter of 1934 and only two in June. During the same period, the most privileged workers were offered forty-eight meat dishes. In the absence of meat, workers preferred not to go to the canteen. Others, disillusioned by canteens that did not allow them to eat properly, did not hesitate to change workplaces in order to try to improve their living conditions and eat at better canteens, or to improve the distribution of food products for their home. Plant managers flooded the Party with complaints about high turnover rates, emphasizing that without improved supplies their plant would not be able to achieve the goals set by the Plan. ${ }^{34}$

An additional source of frustration and anger among the workers, perhaps more disruptive than the bad food itself, was the public discourse about food and canteens. The frustration and anger was not provoked by a discourse that presented an intentionally false picture of a world where everything was marvelous; in other words, the discourse did not aim to construct Potemkin villages. The press, the inspectors, and the politicians were not, for the most part, overtly lying to the population. Rather, by continually promoting an ideal of food service and linking it to an ideal canteen, the unintended consequence of such discourse was to heighten the awareness of a fundamental discrepancy between what should have been and what existed in reality, thus provoking the aforementioned frustration and anger.
Ultimately the discourse functioned in much the same way as the posters from the 1930s studied by Helena Goscilo (2009: 78), that "unwittingly betrayed the degree to which that plenitude thrived as a theoretical ideal that never translated into concrete experience," making lived reality even more unbearable. Official texts, whether newspaper articles or inspection reports, always insisted on the same ideas. Canteens had to be clean, food had to be good and healthy, and the shock workers were supposed to eat more meat and more calories than others. What did workers think about the competition for the best canteen organized in 1932? The official aim was to "improve the quality of food of the workers of the principal sectors of the industry." 35 The winner would have to meet the following criteria: "Proper preparation of food and dishes. Diversity of menus. Increasing the variety of ingredients thanks to auto-supply[...]. Quality of side dishes and their variety. Delicacy of new recipes. High level of calories in the food served." There proved to be a major gap between these requirements and the reality of most Soviet canteens.

In a few instances this idealistic discourse actually exceeded the workers' expectations. Soviet authorities always wanted the workers to eat "good and healthy food." Still, in 1931, an inspection commission, headed by R. Zemliatchka, was scandalized to find at the Sormovo plant canteen tens of tin cans of green peas that had not been used during the past year. It was even more nonplussed by the reaction of the cook who refused to use them for the simple reason that "green peas are not the workers' cup of tea, it is food that is too refined for workers." 36 As scandalous as the situation was for the Stalinist administrators, the cook's words probably reflected the workers' actual preferences. They were certainly expecting food that left them feeling full, rather than "healthy" food. The constant complaint in official texts about shortages of meat also had negative side effects as it raised the workers' level of expectations. Mainly of rural origins, workers were not necessarily used to eating much meat, but they were not getting what they were promised.

Most of their discontent therefore was directed not at the absence of certain foods or even at the poor quality of what was served, but at the fact that the authorities were seen as unable to fulfill their own obligations, unable to keep their own promises, which in turn had serious political consequences. Soviet authorities were supposed to provide food, to nourish the people (Kondratieva 2002), yet the shops were empty and food was scarce. They promised to make "nourishing" food, yet workers ate only shchi without any meat. The idea of a state that failed to pay attention to its citizens and their needs was born from such daily experiences. 
The picture of Soviet catering during the initial Five-Year Plans is far from appetizing. The absence of appealing foods and the permanent structural inadequacies of the catering system played a major role in creating the gloomy atmosphere of the country's forced industrialization. Even when the constraints of this system were loosened slightly after 1935, when rationing was abolished and food became less scarce, the functioning of canteens did not fundamentally change. The same poor practices and shortcomings continued. Workers were still confronted with a monotonous regimen of bland and unappetizing food. A resident of Gorky could still complain in 1938 about having to eat the same pork stew for forty consecutive days. The first years of the 1930 s thus proved to be a fundamental moment as they saw the crystallization of most of the characteristics (most notably the lack of daily care) of the relationships between the Soviet authorities and the population. This was also the period when the canteen menus were established that would continue for many years into the future.

All that having been said, it must be recognized that the "builders of socialism" were actually fed. They were not fed much and they were fed badly, but they were fed. The canteen for many of them was the only possible place to eat, considering the empty shops and the exorbitant prices of collective farm markets. The stakes were high. The implementation of this vast food supply network under difficult political and economic conditions was an extremely complex undertaking. In Western Europe the equivalent process was also slow, beginning in the nineteenth century and early twentieth centuries (Gacon 2014). If the process experienced, especially in France, a significant acceleration during World War I, it nevertheless developed over several decades. By contrast, the "Stalinist" network was virtually created ex nihilo in a few months. It was a vital necessity for the authorities that needed to feed the workers on the construction sites of the industrialization program. It was also a powerful tool in the hands of the Bolsheviks. The power to feed-essentially the power over life and death during these years of hunger - was a central strategy of the Stalinist regime. It was used to control the population and to manage it, since in order to eat you had to be faithful to the state.

Needless to say, canteens were also a place of disenchantment. In that way, canteens were a place where discourses and practices challenged the Stalinist authorities. The obvious gap between the rhetoric about the creation of a new world and the dire reality of the canteens reminded Soviet workers about the failure of the regime to keep its promises. Soviet workers and urban dwellers were confronted daily with the representation of what Helena Goscilo (2009: 78) calls the "official Party line of happiness in plenitude-a never-never, fairy-tale kingdom of enunciated achievement." That was the case of the advertising posters and the paintings she studied or of the repeated demands for healthy, clean, and "cultured" canteens. The only way to deal with such a stark contrast was often to remain impervious to the official discourse. This radical mistrust toward the official discourse would later become characteristic of Soviet society. Open political criticism was strictly repressed by force. When a worker mumbled, "You should eat this soup," to a portrait of Stalin that adorned his canteen, he was arrested the following day by the NKVD secret police. ${ }^{37}$

The Soviet authorities also tried to answer politically to the failure of their project. Stalin's famous formula about the "good life" - "Life has become better, life has become merrier" - put an end, at least symbolically, to the period of the initial FiveYears Plans that had become synonymous with scarcity and famine. The Stalinists developed, after $1935^{-3}$ 6, a strong narrative on food abundance, which was supposed to be an important criterion of their success. The Stalinist luxury stood in stark contrast with the empty shops and canteens at the beginning of the decade. This narrative of abundance, however, proved as empty as the modernization paradigm that prevailed a few years earlier. Food thus serves as a persuasive index of the failures of the Soviet regime. $\mathrm{a}$

\section{Acknowledgments}

I would like to thank the participants of the conference "Food for Thought: Culture and Cuisine in Russia and Eastern Europe, 180o-Present" at the University of Texas at Austin for their insightful comments on an earlier version of this article. Special thanks to Keith Livers and Mary Neuburger for their careful and patient reading and editing of my text, and to the Gastronomica team and two anonymous reviewers who offered helpful comments on this article. This research was made possible by The Centre de Recherches en Histoire des Slaves, the SIRICE laboratory, and the University of Paris 1 Panthéon Sorbonne. I also thank the Uralmachzavod museum in Yekaterinburg and its director Sergey Ageyev for authorizing the publication of the images included here from their collection.

NOTES

1. State Social and Political Archives of the Nizhny Novgorod Region (GOPANO), f. 2, inv. 1, d. 1544, p. 164.

2. After the civil war, the Bolsheviks adopted a new economic policy that allowed elements of the market to participate in the global system, with the state and the cooperative sector playing a significant but less pervasive role. This semi-free system allowed the economy 
to recover, but was abolished by the new Stalinist authorities after 1927 .

3. "It is not only a form of charity and assistance. There's more than that" (Clément 2008).

4. In the novel of Yuri Olesha, Envy, published in 1927, the factory kitchen played a major role in the future imagined by the hero Andrei Babichev.

5. See the photo reporting (1931) of Alexander Rodchenko on the Moscow fabrika kukhnia, which emphasizes its modernity: http:// club.foto.ru/classics/series/46/ (accessed on July 20, 2017).

6. The situation during the first years of Bolshevik power, after 1917 , is more thoroughly studied, mainly in the two capitals of Moscow and Leningrad (Borrero 2003 and McAuley 1991).

7. This city is located on the confluence of the rivers Oka and Volga, 250 miles east of Moscow. In October 1932, it was renamed Gorky, after the famous writer who was born there.

8. A kind of dessert made of fruit juice mixed with potato starch added as a thickening agent.

9. GOPANO, f. 30 , inv. 1, d. 41, p. 44

10. Central Archive of the Nizhny Novgorod Region (CANO), f.

960, inv. 1, d. 107 , p. 92.

11. GOPANO, f. 2 , inv. 1, d. 3073 , p. 37 .

12. These differences were sometimes more theoretical than real. Deficits of food often forced shock workers to eat the same food as their fellow workers. GOPANO, f. 30, inv. 1, d. 274, pp. 33-38: numerous examples for 1933.

13. GOPANO, f. 30 , inv. 1, d. 274 , p. 38

14. CANO, f. 960, inv. 1, d. 167 , p. 12.

15. GOPANO, f. 30 , inv. 1, d. 38 , p. 146 .

16. GOPANO, f. 2 , inv. 1 , d. 670 , p. 59

17. GOPANO, f. 30 , inv. 1, d. 613 , p. 20

18. GOPANO, f. 30 , inv. 1 , d. 274 , p. $3^{8}$.

19. GOPANO, f. 2, inv. 1, d. 1959, p. 141.

20. GOPANO, f. 2 , inv. 1, d. 1959, p. 139

21. Russian State Archive for Social and Political History

(RGASPI), f. 17 , inv. 163, d. 1005 .

22. GOPANO, f. 2 , inv. 1, d. 1303 , p. 3

23. Russian State Archive for Economy (RGAE), f. 8543 , inv. 1, d.

803 , p. $3^{6}$

24. GOPANO, f. 2 , inv. 1, d. 1877 , p. 13 .

25. GOPANO, f. 2 , inv. 1, d. 1877 , pp. 5-6.

26. GOPANO, f. 2 , inv. 1, d. 1877 , p. 4.

27. GOPANO, f. 2 , inv. 1, d. 1877 , p. 4.

28. CANO, f. 5944 , inv. 1, d. 23 , p. 15.

29. Russian Federation State Archives (GARF), f. 1235, inv. 66a, d. 8o, p. 82 .

30. Mikhail Kalinin, a worker of peasant origins who rose to serve as head of the Soviet state, was often compared to the starosta, a rural community leader in pre-revolutionary Russia.

31. "In view of the fact that we still have very bad food, it is not an appropriate idea to discuss this question with the workers: the only result would be to irritate the masses" (GOPANO, f. 30, inv. 1, d.

274, p. 39).

32. GOPANO, f. 3, inv. 1., d. 1064 , p. 8.

33. GOPANO, f. 2, inv. 1, d. 3073 , p. 22

34. GOPANO, f. 2 , inv. 1, d. 1544, p. 86, for example.

35. Resolution of August 19, 1931. CANO, f. 960, inv. 1, d. 107. The competition was organized by the journal Obshchestvennoe pitanie [Collective catering], an organ of the People's Commissariat for Supply (Narkomsnab).

36. RGASPI, f. 17 , inv. 163 , d. 1005.

37. Harvard Project on the Soviet Social System, schedule A, vol. 5 , case 54 (interviewer M.F., type $\mathrm{A}_{3}$ ). Male, 57, Cossack, Peasant. Widener Library, Harvard University.

\section{REFERENCES}

Aunoble, Eric. 2001. "Les ouvriers et le pouvoir à Kharkov de 1920 à 1933, à travers les archives régionales" [Workers and authorities in Kharkov, 1920-1933, through regional archives]. Cahiers du mouvement ouvrier 13-14.

Borrero, Mauricio. 1997. "Communal Dining and State Cafeterias in Moscow and Petrograd, 1917-1921." In Food in Russian History and Culture, ed. Musya Glants and Joyce Toomre, 162-76. Bloomington: Indiana University Press.

- 2003. Hungry Moscow: Scarcity and Urban Society in the Russian Civil War, 1917-1921. New York: Peter Lang.

Bourdieu, Pierre. 1984. Distinction: A Social Critique of the Judgement of Taste. Trans. Richard Nice. Cambridge, MA: Harvard University Press.

Bruegel, Martin, and Bruno Laurioux. 2002. Histoire et identités alimentaires en Europe [History and food identity in Europe]. Paris: Hachette.

Caldwell, Melissa L. 2009. "Introduction: Food and Everyday Life after State Socialism." In Food and Everyday Life in the Postsocialist World, ed. Melissa L. Caldwell, 1-28. Bloomington: Indiana University Press.

Clément, Alain. 2008. "Faut-il nourrir les pauvres? Une perspective historique" [Do we have to feed the poor? An historical perspective]. Anthropology of Food 6. Accessed January 1, 2017. http://aof.revues.org/4283

Dando, William A. 2012. Food and Famine in the 21st Century. Santa Barbara, CA: ABC-CLIO.

Danilov, Viktor Petrovich, O. V. Khlevniuk, and A. Ju. Vatlin. 2000. Kak Lomali Nep: Stenogrammy Plenumov Tsk Vkp (b) 1928-1929 Gg. vol. 2 [How did they break the NEP: Stenograms of the Central Committee Plenums-1928-1929]. Moscow: Mezhdunar. fond "Demokratia": Izd-vo "Materik."

Davies, R. W., and Oleg Khlevnyuk. 1999. "The End of Rationing in the Soviet Union, 1934-1935." Europe-Asia Studies 51: 557-609.

Davies, R. W., and S. G. Wheatcroft. 2004. The Years of Hunger: Soviet Agriculture, 1931-1933. New York: Palgrave Macmillan.

Fitzpatrick, Sheila. 2003. "The Good Old Days." London Review of Books 25(19): 18-20.

Gacon, Stéphane. 2014. "Cantines et alimentation au travail: Une approche comparée, du milieu du xix e siècle à nos jours." [Canteens and food at work: A comparative approach, from the mid-nineteenth century onward]. Le Mouvement Social 247(2): $3-25$.

Glants, Musya, and Joyce Stetson Toomre. 1997. Food in Russian History and Culture. Bloomington: Indiana University Press.

Glushchenko, Irina. 2010. Obshchepit: Mikojan I Sovetskaja Kukhniia. [Collective catering: Mikoyan and Soviet cooking]. Moskva: Izdatel'skij dom GU VShE.

Goldstein, Darra. 2001. "The Spoon, Not the Scepter." Gastronomica 1(2): iii-iv.

Goscilo, Helena. 2009. "Luxuriating in Lack: Plenitude and Consuming Happiness in Soviet Paintings and Posters, 1930s1953." In Petrified Utopia: Happiness Soviet Style, ed. Marina Balina and Evgeny Dobrenko, 54-78. Londres: Anthem Press.

Grignon, Claude, and Christiane Grignon. 1980. "Styles d'alimentation et goûts populaires" [Food styles and popular tastes]. Revue française de sociologie 21(4): 531-69.

Gronow, Jukka. 2003. Caviar with Champagne: Common Luxury and the Ideals of the Good Life in Stalin's Russia. Oxford and New York: Berg.

Hessler, Julie. 2004. A Social History of Soviet Trade: Trade Policy, Retail Practices, and Consumption, 1917-1953. Princeton, NJ: Princeton University Press. 
Kaplan, Steven L. 1976. Bread, Politics and Political Economy in the Reign of Louis XV. The Hague: Martinus Nijhoff.

Kondratieva, Tamara. 2002. Gouverner et nourrir: Du pouvoir en Russie, xvie-xxe siècles [To rule and to feed: On power in Russia, 16th-2oth centuries]. Paris: Belles lettres.

Long, Vicky. 2014. "Situating the Factory Canteen in Discourses of Health and Industrial Work in Britain (1914-1939)." Le Mouvement social 247(2): 65-83.

McAuley, Mary. 1991. Bread and Justice: State and Society in Petrograd, 1917-1922. Oxford and New York: Clarendon Press, Oxford University Press.

Ministry of the Food Industry (USSR). 1954. Kniga O Vkusnoj I Zdorovoj Piš e [The book of good and healthy cooking]. Moscow: Ministry of the Food Industry.

Munro, George E. 1997. "Food in Catherinian St. Petersburg." In Food in Russian History and Culture, ed. Musya Glants and Joyce Toomre, 31-48. Bloomington: Indiana University Press.

Nérard, François-Xavier. 2013. "Prizraki terrora: Liudy obshchestvennogo pitaniia v usloviakh stalinskogo terrora" [The ghosts of terror: People of the collective catering system during Stalin's terror]. In Istoriia stalinizma: Zhizn'v terrore. Sotsial'nye aspekty repressii [History of Stalinism: Life under terror-Social dimensions of repression], ed. A. Sorokin, A. Kobak, and O. Kuvaldina, 266-73. Moscow: Rosspen. - 2014. "Nourrir les constructeurs du socialisme: Cantines et question alimentaire dans L'URSS des Premiers Plans Quinquennaux (1928-1935)" [To feed the builders of socialism: Canteens and food system in the USSR during the first Five-Year Plans]. Le Mouvement Social 247(2): 85-103.

Ochoa, Enrique. 2000. Feeding Mexico: The Political Uses of Food since 1910. Wilmington, DE: Scholarly Resources.

Olesha, Urij Karlovich, and Marian Schwartz. 2004. Envy. New York: New York Review Books.
Osokina, E. A. 1998. Za fasadom "stalinskogo uzobiliia": Raspredelenie $i$ rynok $v$ snabzhenii naseleniia $v$ gody industrializatsii (1927-1941) [Beyond the facade of Stalinist abundance: The role of distribution and the market in supplying the population in the years of industrialization, 1927-1941]. Moskva: ROSSPEN.

- 2001. Our Daily Bread: Socialist Distribution and the Art of Survival in Stalin's Russia, 1927-1941. Armonk, NY: M.E. Sharpe. Ricciardi, Ferruccio. 2014. "La cantine au prisme du paternalisme industriel: Alimentation et consentement à l'usine de Dalmine (Lombardie) entre Fascisme et République" [The canteen through the prism of industrial paternalism: Food and consent at the factory of Dalmine (Lombardy) between Fascism and the Republic]. Le Mouvement Social 247(2): 105-21.

Rothstein, Halina, and Robert Rothstein. 1997. "The Beginnings of Soviet Culinary Arts." In Food in Russian History and Culture, ed. Musya Glants and Joyce Toomre, 177-94. Bloomington: Indiana University Press.

Virlouvet, Catherine. 1994. "Les lois frumentaires d'Époque Républicaine" [Frumentary laws during the Republican Period]. In Le ravitaillement en blé de Rome et des centres urbains des débuts de la République jusqu'au haut empire: Actes du colloque de Naples, 14-16 février 1991 [Wheat supplies in Rome and urban centers from the beginning of the Republic to the Early Roman Empire: Proceedings of the Naples conference, 14-16 February 1991], 11-29. Naples and Rome: Centre Jean Bérard; Ecole française de Rome.

Yang, Jisheng. 2012. Tombstone: The Untold Story of Mao's Great Famine. New York: Farrar, Straus and Giroux.

Zweiniger-Bargielowska, Inna. 2011. "Fair Shares? The Limits of Food Policy in Britain during the Second World War." In Food and War in Twentieth-Century Europe, ed. I. ZweinigerBargielowska, R. Duffett, and A. Drouard, 125-38. Farnham: Burlington. 